Original Article

\title{
Characterization of the species of genus Physa on the basis of typological species concept from Central Punjab
}

\author{
Caracterização das espécies do gênero Physa com base no conceito tipológico de \\ espécie do Punjab Central
}

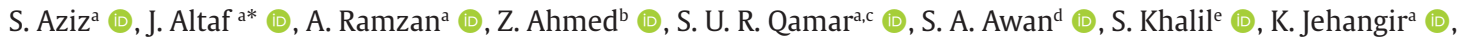

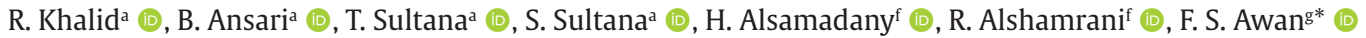 \\ aGovernment College University Faisalabad Department of Zoology, Punjab, Pakistan. \\ 'University of Agriculture, Faisalabad, Department of Plant Breeding and Genetics; Center for Advanced Studies in Agriculture and Food \\ Security (CAS-AFS), Faisalabad, Pakistan. \\ 'Chulabhorn Graduate Institute, Department of Applied Biological Sciences, 54 Kamphaeng Phet 6 Road, Lak Si, Bangkok, Thailand. \\ dUniversity of Agriculture, Faisalabad Department of Computer Science, Faisalabad, Pakistan. \\ eThe Islamia University Bahawalpur Department Forestry Range \& Wildlife Management, Faculty of Agriculture \& Environmental Science, \\ Bagdad Ul Jadeed Campus, Bahawalpur, Pakistan. \\ fKing Abdulaziz University, Faculty of Science, Department of Biological Sciences, Jeddah, Saudi Arabia. \\ sUniversity of Agriculture, Faisalabad, Centre of Agricultural Biochemistry and Biotechnology, Faisalabad, Pakistan
}

\begin{abstract}
Physids belong to Class Gastropoda; Phylum Mollusca have important position in food web and act as bio indicators, pests and intermediate host. Being resistant these are called cockroaches of malacology. Physid snails were collected from different water bodies of Faisalabad (Punjab) and were identified up to species using morphological markers. The morphometry of the specimens was carried out with the help of a digital Vernier caliper in millimeters ( $\mathrm{mm}$ ) using linear measurement of shell characters. Linear regression analysis of the AL/SW ratio vs AL and SL/SW ratio vs AL indicated that allometric growth exists only in Physa acuta when compared with P.gyrina and P. fontinalis. This study will lead to assess the status of the Physid species in Central Punjab. The Principal component analysis shows that the Component 1 (Shell Length) and component 2 (Shell Width) are the most prolific components and nearly 80 percent of the identification. The distance between $P$. acuta and $P$. fontinalis is $5.4699, P$. acuta and $P$. gyrina is 7.6411, P. fontinalis and P. gyrina is 16.6080 showing that $P$. acuta resembles with $P$. fontinalis, and both these specimens donot resemble with $P$. gyrina. P.acuta is an invasive species and shows bioactivity making it a potent candidate for bioactive substances.
\end{abstract}

Keywords: Mollusca, Physa, polymorphism, principal components, discriminant analysis, Punjab.

\begin{abstract}
Resumo
Os físidos pertencem à classe Gastropoda; o filo Mollusca possui importante posição na teia alimentar e atua como bioindicador, praga e hospedeiro intermediário. Por serem resistentes, são chamadas baratas de malacologia. Os caramujos físidos foram coletados em diferentes corpos d'água de Faisalabad (Punjab) e identificados até as espécies por meio de marcadores morfológicos. A morfometria dos corpos de prova foi realizada com auxílio de paquímetro digital Vernier em milímetros $(\mathrm{mm})$ por meio de medida linear dos caracteres da casca. A análise de regressão linear da razão AL / SW vs. AL e razão SL / SW vs. AL indicou que o crescimento alométrico existe apenas em Physa acuta quando comparado com $P$. gyrina e $P$. fontinalis. Este estudo levará a avaliar a situação das espécies de físido no Punjab Central. A análise do componente principal mostra que o componente 1 (comprimento da casca) e o componente 2 (largura da casca) são os componentes mais prolíficos e quase $80 \%$ da identificação. A distância entre $P$. acuta e $P$. fontinalis é 5,4699, $P$. acuta e $P$. gyrina é 7,6411, $P$. fontinalis e $P$. gyrina é 16,6080, mostrando que $P$. acuta se assemelha a $P$. fontinalis, e ambos os espécimes não se parecem com $P$. gyrina. $P$. acuta é uma espécie invasora e apresenta bioatividade, tornando-se uma candidata potente para substâncias bioativas.
\end{abstract}

Palavras-chave: Mollusca, Physa, polimorfismo, componentes principais, análise discriminante, Punjab.

*e-mail: javariaaltafuaar@yahoo.com; awanfaisal@yahoo.com

Received: December 24, 2020 - Accepted: February 09, 2021 


\section{Introduction}

In Physa snails simple linear measurements of the shell are quite useful for the characterization of the species and can be analyzed using Principal Component Analysis and Discriminant as these are being practiced by taxonomists since long (Dillon Junior and Jacquemin, 2015). In North America, Physids are the most abundant and widespread freshwater gastropods (Burch, 1982). Physa acuta has been documented as invasive around the world. Its management has not been carried as the taxonomic characterization of Physa acuta is fragmentary. A number of studies on the basis of reproductive biology has shown that there is an over estimation in the number of species of family Physidae due to which two genus classification system of Physidea has been proposed by Wethington and Lydeard (2007) showing nearly 10 species belonging to genus Physa, with $P$. heterostropha and $P$. cubensis being the junior synonyms of the cosmopolitan P. acuta (Draparnaud, 1805), and $P$. hendersoni being the junior synonym of $P$. pomilia

There are various synonyms of Physa acuta such as P. heterostropha, P. integra and P. virgata (Dillon Junior et al., 2002; Wethington, 2004). The freshwater family Physidae (Pulmonata: Basommatophora) has a holarctic distribution, extending into Central and South America (Wethington and Lydeard, 2007). Physids have been introduced around the world and prominently in aquatic ecosystems, particularly in lentic habitats. Physidae are hermaphrodites and can be distinguished from other pulmonates by the certain major characteristics i.e. a high-spired sinistral shell, radula with teeth in $\mathrm{V}$-shaped rows, simple jaw with no lateral processes, and lack of both haemoglobin and pseudobranchia. Family Physidae has a unique characteristic that they have an extended mantle edge that can partly cover the shell, as well as the presence of a preputial gland (Te, 1978). The Physa are cosmopolitan in distribution (Albrecht et. al., 2009). These snails are found abundant in wet season (July-September) as compared to dry season (December-February) due to less rain fall, however other abiotic factors also influence the distribution and abundance of these gastropods (Altaf et al., 2016; Qamar et al., 2017)

The Physa acuta was first time revealed in Pakistan by Begum and Nazneen (1991) while Physa gyrina was depicted by Khatoon and Ali (1978). The Physa fontinalis was first time reported from the region by Altaf et al. (2017b) A number of reviews on the freshwater snails of Sindh, KPK, Balochistan and Punjab have been completed. However, still the information about Physid snails is fragmentary. The freshwater snail fauna of Pakistan is minimum known in Asia. The aim of the present investigation is to study the taxonomical characterization of three Physa species from Central Punjab The species produce bioactive substances and show strong activity against $S$. aureus, E. coli, and P.auroginosa. These are strong candidate for the antibiotic drug development (Altaf et al., 2018).

\section{Materials and Method}

\subsection{Study area and sampling sites}

Faisalabad district is the third one largest city of Pakistan and is present in Punjab province of Pakistan, covering an area of $5960 \mathrm{~km}^{2}$ at spherical coordinates of $31.4504^{\circ} \mathrm{N}$, $73.1350^{\circ} \mathrm{E}$ and is located at an altitude of $184 \mathrm{~m}$ above sea level (Kahlown et al., 2006). The population of Faisalabad is $7,874,790$, of which $52.2 \%$ is rural and $47.8 \%$ is urban population and a having a density of $1,321 / \mathrm{km}^{2}$ (Figure 1 ). The Physid snails from the different water bodies of the agroecosystem of the Faisalabad were collected by random sampling during the months of October to March, by using hand-picking methods from irrigation canals of Faisalabad (Figure 2). Sixty two villages were selected randomly on the using lottery method (Figure 3). Every village was visited once during this period, at the dawn or dusk. The point of irrigation canals with the vegetation/tree cover was keenly observed for an hour to check the presence of species specimen for collection. The specimens were identified upto genus, on site, collected in small specimen bottles and were brought to the lab for preservation in $99.9 \%$ ethyl alcohol. All the specimen bottles were labelled with the collectors name, date, and ecological information.

\subsection{Morphometric analysis}

The snail samples were identified with the help of keys and the diagrams given by Albrecht et al. (2009) and www.animalbase.org. The morphometry of the specimens was carried out with the help of a digital Vernier caliper in millimeters ( $\mathrm{mm}$ ) using shell characters i.e number of whorls, height and diameter of shells, umbilicus, coiling of shells, shape and colour of shells, shape and size of aperture, presence or absence of operculum. The picture of each snail was taken by photocamera following Altaf et al., 2017b (Figure 2).

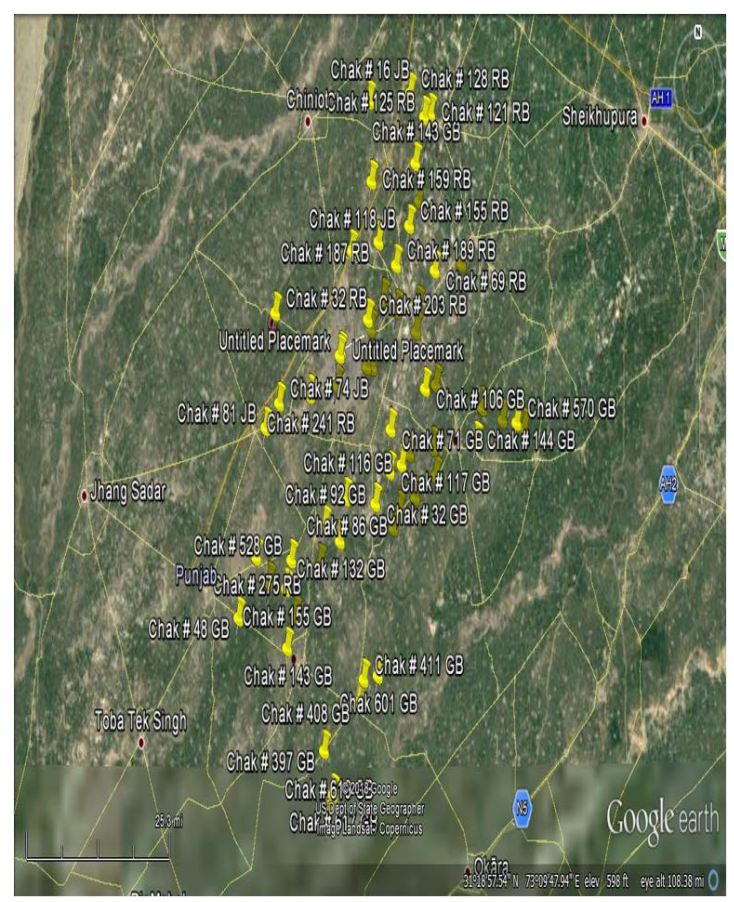

Figure 1. Sampling sites in district Faisalabad. 


\section{Results}

Three species of the genus Physa i.e. Physa acuta, Physa fontinalis and Physa gyrina were found from sixty different villages of Faisalabad

\subsection{Physa acuta (Draparnaud, 1805)}

The morphometric ranges and means of Physa acuta in villages linked to Rakh Branh, Ghongera Branh and Jinnah Branch (Table 1.) shows shell length ranges within $6.12 \mathrm{~mm}$ $-10.9 \mathrm{~mm}$ in all the three villages with an insignificant difference. The shell width ranges from $2.92 \mathrm{~mm}-4.7 \mathrm{~mm}$, aperture length lies within the range of 3.95-5.8, the range of aperture width lies within 1.99-2.67, penultimate whorl length lies within the range if $1.67-5.9$, spire height with a

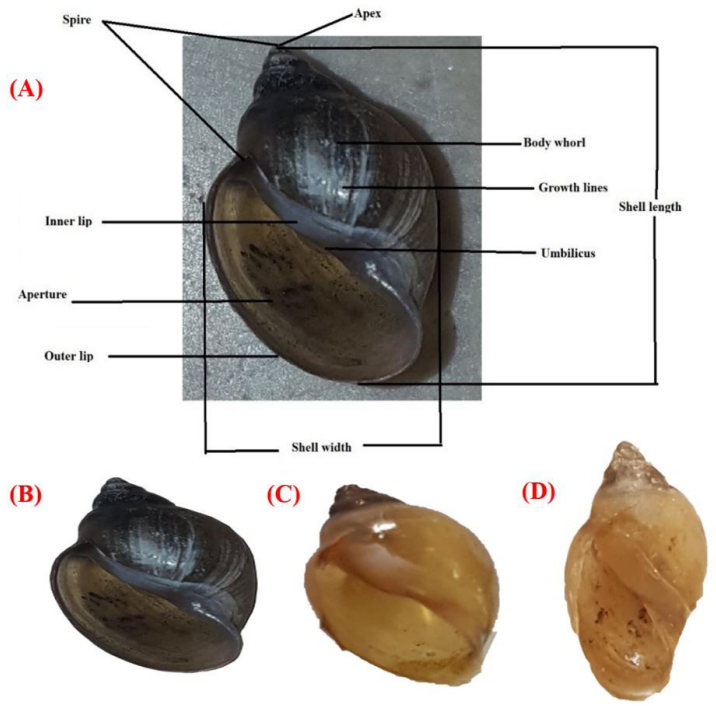

Figure 2. (A) Morphological characteristics of snails of genus Physa; (B) Physa acuta; (C) Physa fontinalis; (D) Physa gyrina. range of 1.25-4.2 and the range of body whorl length lies within 2.46-4.17 range. These ranges show that there is very less differences in all the three branched villages. A colour variation is present in the shell from pale yellowish to transparent pale shiny colour. 3-4 numbers of whorls are present (Table 1; Figure 3).

\subsection{Physa fontinalis (Linaeus, 1758)}

The shell of Physa fontinalis is sinistral and oval in shape. The morphometric ranges and means of Physa fontinalis in villages linked to Rakh Branch and Ghogera Branch shown in (Table 2 and Figure 3) showing shell length ranges within $6.28 \mathrm{~mm}-12.48 \mathrm{~mm}$ in both villages with an insignificant difference. The shell width ranges from $4.33 \mathrm{~mm}-5.6 \mathrm{~mm}$, aperture length lies within the range of $5.02 \mathrm{~mm}-7.31 \mathrm{~mm}$, the range of aperture width lies within $2.5 \mathrm{~mm}-3.42 \mathrm{~mm}$, penultimate whorl length lies within the range if $1.79 \mathrm{~mm}-10.98 \mathrm{~mm}$, spire height with a range of $1.25 \mathrm{~mm}-5.2 \mathrm{~mm}$ and the range of body whorl length lies within $3.3 \mathrm{~mm}-5.1 \mathrm{~mm}$ range. These ranges show that there is very less differences in all the three branched villages. The shell is thin light horny coloured with a blunt and rounded apex; 3-4 numbers of whorls are present with upper convex whorls.

\subsection{Physa gyrina (Linnaeus, 1758)}

The morphometric ranges and means of Physa gyrina in villages linked to Ghongera Branh (Table 3; Figure 2) showing shell length ranges within $7.03 \mathrm{~mm}-8.9 \mathrm{~mm}$ in Ghongera Branch villages with an insignificant difference. The shell width ranges from $4.1 \mathrm{~mm}-6.9 \mathrm{~mm}$, aperture length lies within the range of $4.69 \mathrm{~mm}-6.13 \mathrm{~mm}$, the range of aperture width lies within $1.95 \mathrm{~mm}-3.06 \mathrm{~mm}$, penultimate whorl length lies within the range if $5.66 \mathrm{~mm}-7.09 \mathrm{~mm}$, spire height with a range of $1.96 \mathrm{~mm}-3.98 \mathrm{~mm}$ and the range of body whorl length lies within $2.98 \mathrm{~mm}-4.5 \mathrm{~mm}$ range. Umbilicus is not present and the coiling of shell is

Table 1. Morphometric parameters of Physa acuta (Linnaeus, 1758).

\begin{tabular}{lcccccccccc}
\hline $\begin{array}{l}\text { Morphometric } \\
\text { Characters }\end{array}$ & $\begin{array}{c}\text { Range } \\
\text { (RB villages) }\end{array}$ & Mean & SD & $\begin{array}{c}\text { Range } \\
\text { (GB Village) }\end{array}$ & Mean & SD & $\begin{array}{c}\text { Range } \\
\text { (JB villages) }\end{array}$ & Mean & $\begin{array}{c}\text { SD } \\
\text { Overall } \\
\text { Mean }\end{array}$ \\
\hline Shell length & $6.56-12.02$ & 8.69 & 1.52 & $6.12-10.9$ & 8.17 & 1.36 & $6.23-9.3$ & 7.1 & 0.93 & 7.98 \\
Shell width & $3.3-6.57$ & 4.93 & 0.91 & $2.92-6.57$ & 4.78 & 1.08 & $2.92-5.9$ & 3.77 & 0.83 & 4.49 \\
Aperture length & $4.54-7.8$ & 6.07 & 0.89 & $3.95-8.12$ & 5.65 & 1.1 & $4.02-6.76$ & 4.72 & 0.83 & 5.48 \\
Aperture width & $2.15-7.5$ & 3.17 & 1.49 & $1.97-3.69$ & 2.67 & 0.39 & $1.99-3.21$ & 2.36 & 0.37 & 2.73 \\
Penultimate & $4-10.69$ & 6.53 & 2.07 & $1.67-9.45$ & 6.45 & 1.69 & $4.99-7.94$ & 6.26 & 0.81 & 6.41 \\
whorl length & & & & & & & & & & \\
Spire height & $1.25-5.2$ & 2.98 & 1.33 & $1.2-4.75$ & 2.45 & 0.97 & $1.56-2.41$ & 1.89 & 0.23 & 2.44 \\
Body whorl & $2.46-9.9$ & 3.96 & 1.84 & $2.46-6.53$ & 3.65 & 0.8 & $2.46-4$ & 3.13 & 0.44 & 3.58 \\
length & & & & & & & & & & \\
No. of whorls & $3.0-4.0$ & 3.2 & 0.4 & $3.0-4.0$ & 3.09 & 0.29 & $3.0-3.0$ & 3 & 0 & 3.09 \\
AL/SW & $0.47-0.71$ & 0.57 & 0.07 & $0.45-0.71$ & 0.58 & 0.06 & $0.45-0.63$ & 0.53 & 0.06 & 0.56 \\
SL/SW & $1.40-2.11$ & 1.78 & 0.21 & $1.40-2.23$ & 1.74 & 0.19 & $1.58-2.23$ & 1.92 & 0.2 & 1.81 \\
\hline
\end{tabular}


Table 2. Morphometric parameters of Physa fontinalis.

\begin{tabular}{|c|c|c|c|c|c|c|c|c|c|c|}
\hline $\begin{array}{l}\text { Morphometric } \\
\text { Characters }\end{array}$ & $\begin{array}{c}\text { Range } \\
\text { (RB villages) }\end{array}$ & Mean & SD & $\begin{array}{c}\text { Range } \\
\text { (GB Villages) }\end{array}$ & Mean & SD & $\begin{array}{c}\text { Range } \\
\text { (JB villages) }\end{array}$ & Mean & SD & $\begin{array}{c}\text { Overall } \\
\text { mean }\end{array}$ \\
\hline Shell length & $7.54-12.03$ & 9.83 & 1.3 & $6.28-2.48$ & 10.16 & 1.61 & NA & - & - & 9.99 \\
\hline Shell width & $4.33-6.4$ & 5.62 & 0.62 & $3.33-6.4$ & 5.52 & 0.73 & NA & - & - & 5.57 \\
\hline Aperture length & $5.93-8.12$ & 7.08 & 0.77 & $5.02-8.34$ & 7.31 & 0.97 & NA & - & - & 7.19 \\
\hline Aperture width & $2.7-7.6$ & 3.37 & 1.33 & $2.5-7.7$ & 3.42 & 1.37 & NA & - & - & 3.39 \\
\hline $\begin{array}{l}\text { Penultimate } \\
\text { whorl length }\end{array}$ & $2.23-10.98$ & 7.33 & 2.68 & $1.79-10.98$ & 7.66 & 2.78 & NA & - & - & 7.49 \\
\hline Spire height & $1.25-5.05$ & 3.44 & 1.18 & $1.25-5.25$ & 3.26 & 1.41 & NA & - & - & 3.35 \\
\hline $\begin{array}{l}\text { Body whorl } \\
\text { length }\end{array}$ & $2.98-9.9$ & 4.59 & 1.77 & $2.98-10.28$ & 5.1 & 2.35 & NA & - & - & 4.85 \\
\hline No. of whorls & $3.0-4.0$ & 3.6 & 0.49 & $3.0-4.0$ & 3.88 & 0.32 & NA & - & - & 3.74 \\
\hline AL/SW & $0.49-0.69$ & 0.58 & 0.49 & $0.45-0.61$ & 0.55 & 0.03 & & & - & 0.57 \\
\hline SL/SW & $1.44-2.03$ & 1.75 & 0.14 & $1.63-2.23$ & 1.84 & 0.14 & & & - & 1.79 \\
\hline
\end{tabular}

Table 3. Morphometric parameters of Physa gyrina (Linnaeus, 1758).

\begin{tabular}{|c|c|c|c|c|c|c|c|c|c|c|}
\hline \multirow{2}{*}{$\begin{array}{l}\text { Morphometric } \\
\text { Characters }\end{array}$} & \multirow{2}{*}{$\begin{array}{c}\text { Range } \\
\text { (RB } \\
\text { villages) }\end{array}$} & \multirow[b]{2}{*}{ Mean } & \multirow[b]{2}{*}{ SD } & \multirow{2}{*}{$\begin{array}{c}\text { Range } \\
\text { (GB } \\
\text { Villages) }\end{array}$} & \multirow[b]{2}{*}{ Mean } & \multirow[b]{2}{*}{ SD } & \multirow{2}{*}{$\begin{array}{c}\text { Range } \\
\text { (JB } \\
\text { villages) }\end{array}$} & \multirow[b]{2}{*}{ Mean } & \multirow[b]{2}{*}{ SD } & \multirow{2}{*}{$\begin{array}{c}\text { Overall } \\
\text { mean }\end{array}$} \\
\hline & & & & & & & & & & \\
\hline Shell length & $7.54-12.03$ & 9.83 & 1.3 & $6.28-2.48$ & 10.16 & 1.61 & NA & - & - & 9.99 \\
\hline Shell width & $4.33-6.4$ & 5.62 & 0.62 & $3.33-6.4$ & 5.52 & 0.73 & NA & - & - & 5.57 \\
\hline Aperture length & $5.93-8.12$ & 7.08 & 0.77 & $5.02-8.34$ & 7.31 & 0.97 & NA & - & - & 7.19 \\
\hline Aperture width & $2.7-7.6$ & 3.37 & 1.33 & $2.5-7.7$ & 3.42 & 1.37 & NA & - & - & 3.39 \\
\hline $\begin{array}{l}\text { Penultimate } \\
\text { whorl length }\end{array}$ & $2.23-10.98$ & 7.33 & 2.68 & $1.79-10.98$ & 7.66 & 2.78 & NA & - & - & 7.49 \\
\hline Spire height & $1.25-5.05$ & 3.44 & 1.18 & $1.25-5.25$ & 3.26 & 1.41 & NA & - & - & 3.35 \\
\hline $\begin{array}{l}\text { Body whorl } \\
\text { length }\end{array}$ & $2.98-9.9$ & 4.59 & 1.77 & $2.98-10.28$ & 5.1 & 2.35 & NA & - & - & 4.85 \\
\hline No. of whorls & $3.0-4.0$ & 3.6 & 0.49 & $3.0-4.0$ & 3.88 & 0.32 & NA & - & - & 3.74 \\
\hline AL/SW & $0.49-0.69$ & 0.58 & 0.49 & $0.45-0.61$ & 0.55 & 0.03 & & & - & 0.57 \\
\hline SL/SW & $1.44-2.03$ & 1.75 & 0.14 & $1.63-2.23$ & 1.84 & 0.14 & & & - & 1.79 \\
\hline Shell coiling & Sinistral & & & & & & & & & \\
\hline
\end{tabular}

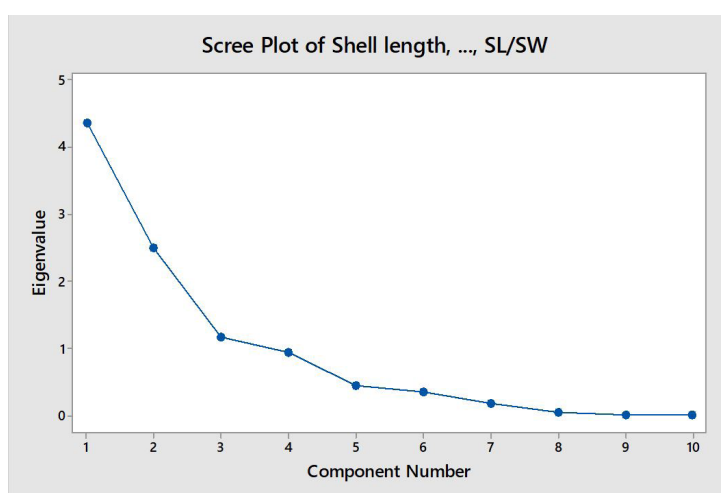

Figure 3. Scree plot between principal components and the eigenvalue. sinistral. Snails were not found in the Jinnah Branch and Rakh branches of Faisalabad.

\subsection{Statistical analysis}

\subsubsection{Linear regression analysis}

Linear regression analysis of the $\mathrm{AL} / \mathrm{SW}$ ratio vs AL and $\mathrm{SL} / \mathrm{SW}$ ratio vs AL indicated that allometric growth exists only in Physa acuta in comparison to other two species of genus Physa. AL/SW ratio increased insignificantly ( $\mathrm{p}>0.05$ ) in all three species as AL increased ( $r$ for Physa acuta, Physa fontinalis and Physa gyrina =0.031, 0.1363 and 0.0692 respectively), but In Physa acuta SL/SW ratio decreased significantly $(\mathrm{p}<0.05)$ as AL increased $(\mathrm{r}=0.043)$ and In Physa fontinalis and Physa gyrina SL/SW ratio increased 
insignificantly $(\mathrm{p}>0.05)$ as AL increased ( $\mathrm{r}$ for Physa fontinalis and Physa gyrina $=0.0165,0.3653$ respectively). The slopes of both linear regression lines significantly suggested that elongation of shell length and enlargement of shell width do not probably contribute equally to the growth of Physa acuta (Table 4).

\subsubsection{Principal component analysis}

Principal Component Analysis is performed for multivariate analysis to identify the smaller number of uncorrelated variables, Principal Components from our data set. PCA explains the maximum amount of variance with the fewest number of Pricipal Components. This method of analysis for specie identification has been previously supported and used for analysis of heretability of shell morphometrics of Physa acuta (Dillon Junior and Jacquemin, 2015). PC1 (Shell Length) contributes $43.7 \%$ of all variables. The variables which correlate with PC1 are Shell length, Shell Width, Aperture Length, Aperture Width, Penultimate Whorl Length, Spire Height, Body Whorl Length, Whorls with the values of $0.469,0.386,0.434,0.037,0.240,0.356$, 0.366 , and 0.345 respectively (Table 5 ).

The scree plot indicates that first three componets (Shell Length, Shell Width, Aperture Length) contribute their maximum part in species identification because their
Eigenvalue is more than 1 with the pattern of $4.3714,2.4908$ and 1.1648 respectively (Table 5; Figure 3). Component 1 (Shell Length) and component 2 (Shell Width) are the most prolific components in our data set. In the scoreplot, clusters on both sides represent the maximum differences between three species, Physa acuta, Physa fontinalis and Physa gyrina and minimum differences within these species. The second componet (Shell Width) does not contribute effectively in the identification of species as shown in the graph of score plot (Figure 4).

Loading plot visually represents the results for first two components (Shell Length and Shell Width). Our results represent that Shell Length, Shell Width, Aperture Length, Aperture Width, Penultimate Whorl Length, Spire Height, Body Whorl Length, Whorls, and SL/SW have large positive loading on $1^{\text {st }}$ component. AL/SW is negatively loaded on $1^{\text {st }}$ component. The parameters, Shell Length, Body Whorl Length, Spire Height, Whorls, SL/SW are positively loaded on second component. Aperture Length, Penultimate Whorl Length, Shell Width, Aperture Width and AL/SW are negatively loaded on second component (Figure 5). Outlier plot represents the outliers in our results. There is less number of outliers above the reference line as shown in graph. Most of the values are below the reference line which shows data is correct and no miss identification of species (Table 6; Figure 6).

Table 4. Regression equations indicating the allometric growth of the three studied snails.

\begin{tabular}{llllc}
\hline \multicolumn{1}{c}{ Species } & Regression Value & r-value & N & p-value \\
\hline P. acuta & $\mathrm{SL} / \mathrm{SW}=1.7973-0.0141 \mathrm{AL}$ & 0.043 & 92 & $\mathrm{P}<0.05$ \\
& $\mathrm{AL} / \mathrm{SW}=1.1903+0.0053 \mathrm{AL}$ & 0.031 & 92 & $\mathrm{P}>0.05$ \\
P. fontinalis & $\mathrm{SL} / \mathrm{SW}=0.7162+0.1714 \mathrm{AL}$ & 0.0165 & 69 & $\mathrm{P}>0.05$ \\
& $\mathrm{AL} / \mathrm{SW}=1.1976+0.0152 \mathrm{AL}$ & 0.1363 & 69 & $\mathrm{P}>0.05$ \\
P. gyrina & $\mathrm{SL} / \mathrm{SW}=1.1655+0.0809 \mathrm{AL}$ & 0.3653 & 9 & $\mathrm{P}>0.05$ \\
& $\mathrm{AL} / \mathrm{SW}=0.2305+0.1166 \mathrm{AL}$ & 0.0692 & 9 & $\mathrm{P}>0.05$ \\
\hline
\end{tabular}

Table 5. Eigenanalysis of the Correlation Matrix.

\begin{tabular}{lcccccccccc}
\hline \multicolumn{1}{c}{ Variables } & PC1 & PC2 & PC3 & PC4 & PC5 & PC6 & PC7 & PC8 & PC9 & PC10 \\
\hline Shell length & 0.469 & -0.006 & -0.047 & -0.017 & 0.156 & 0.049 & -0.231 & -0.529 & 0.3 & 0.572 \\
Shell Width & 0.386 & -0.354 & -0.125 & 0.017 & 0.061 & 0.052 & -0.151 & -0.42 & 0.292 & 0.647 \\
Aperture Length & 0.434 & -0.078 & 0.131 & 0.114 & 0.248 & 0.405 & -0.364 & 0.641 & 0.07 & 0.037 \\
Aperture Width & 0.037 & -0.103 & 0.73 & 0.573 & 0.178 & -0.207 & 0.193 & -0.117 & 0.007 & 0.013 \\
Penultimate Whorl Length & 0.24 & -0.171 & 0.294 & -0.711 & 0.321 & -0.307 & 0.322 & 0.139 & 0.018 & 0.007 \\
Spire Height & 0.356 & 0.169 & -0.397 & 0.28 & 0.162 & 0.145 & 0.745 & 0.082 & 0.022 & 0.006 \\
Body Whorl Length & 0.366 & 0.199 & -0.194 & 0.174 & -0.233 & -0.772 & -0.216 & 0.245 & 0.011 & 0.045 \\
WHORLS & 0.345 & 0.084 & 0.084 & -0.157 & -0.801 & 0.252 & 0.181 & -0.012 & 0.011 & 0.006 \\
AL/SW & -0.045 & -0.612 & -0.157 & 0.088 & -0.166 & -0.11 & 0.112 & 0.082 & 0.547 & 0.483 \\
SL/SW & 0.047 & 0.616 & 0.117 & -0.102 & 0.162 & 0.027 & -0.061 & -0.164 & 0.721 & 0.129 \\
Eigenvalue & 4.3714 & 2.4908 & 1.1648 & 0.9426 & 0.4368 & 0.3525 & 0.1785 & 0.049 & 0.0121 & 0.0015 \\
Proportion & 0.437 & 0.249 & 0.116 & 0.094 & 0.044 & 0.035 & 0.018 & 0.005 & 0.001 & 0 \\
Cumulative & 0.437 & 0.686 & 0.803 & 0.897 & 0.941 & 0.976 & 0.994 & 0.999 & 1 & 1 \\
\hline
\end{tabular}




\subsubsection{Discriminant analysis}

Discriminant analysis was done to classify the observations into two or more groups and to determine how accurately the observations are classified into the known groups. True group represents that all the observations are correctly placed in the model. The total number of specimens was 171 out of which 134 members were correctly identified with $78.4 \%$ correction proportion. In

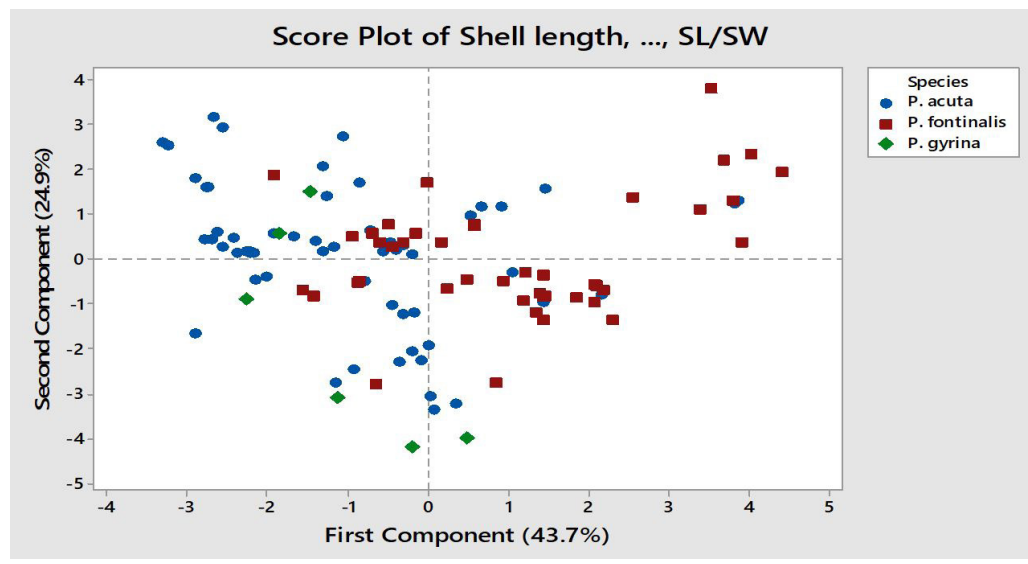

Figure 4. Score plot between the First Principal Component and the Second Component.

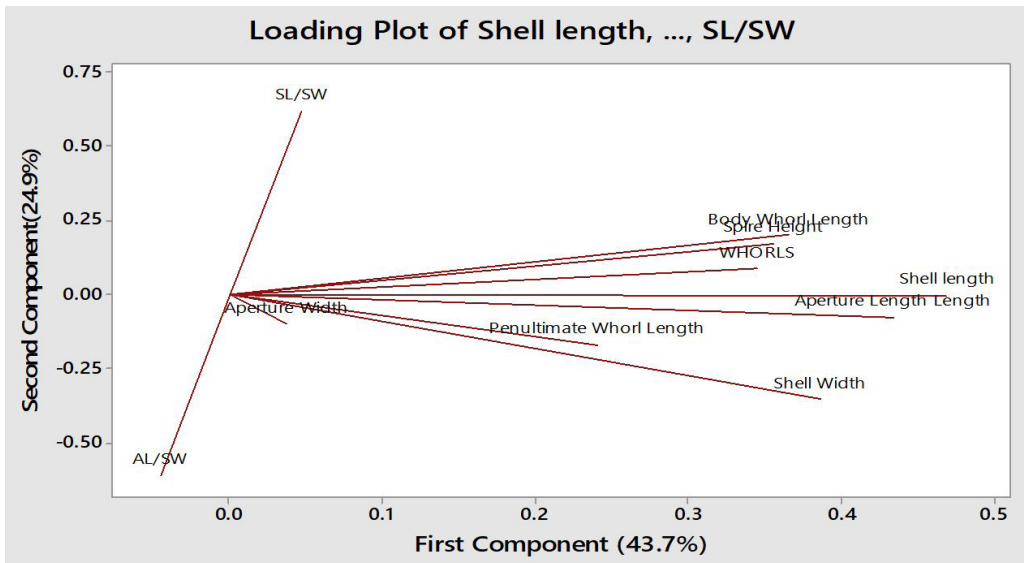

Figure 5. Loading Plot between the First Principal Component and The Second Principal Component.

Table 6. Discriminant analysis among three Physid species.

\begin{tabular}{|c|c|c|c|}
\hline \multirow{2}{*}{ Put into Group } & P. acuta & P. fontinalis & P. gyrina \\
\hline & True group & True group & True group \\
\hline Species & P. acuta & P. fontinalis & P. gyrina \\
\hline P. acuta & 79 & 13 & 3 \\
\hline P. fontinalis & 10 & 52 & 0 \\
\hline P. gyrina & 9 & 2 & 3 \\
\hline Total N & 98 & 68 & 6 \\
\hline $\mathrm{N}$ correct & 79 & 52 & 3 \\
\hline Proportion & 0.806 & 0.776 & 0.5 \\
\hline \multicolumn{4}{|l|}{$\mathbf{N}=171$} \\
\hline \multicolumn{4}{|l|}{$\mathbf{N}$ Correct $=134$} \\
\hline ProportionCorrect $=0.784$ & & & \\
\hline
\end{tabular}




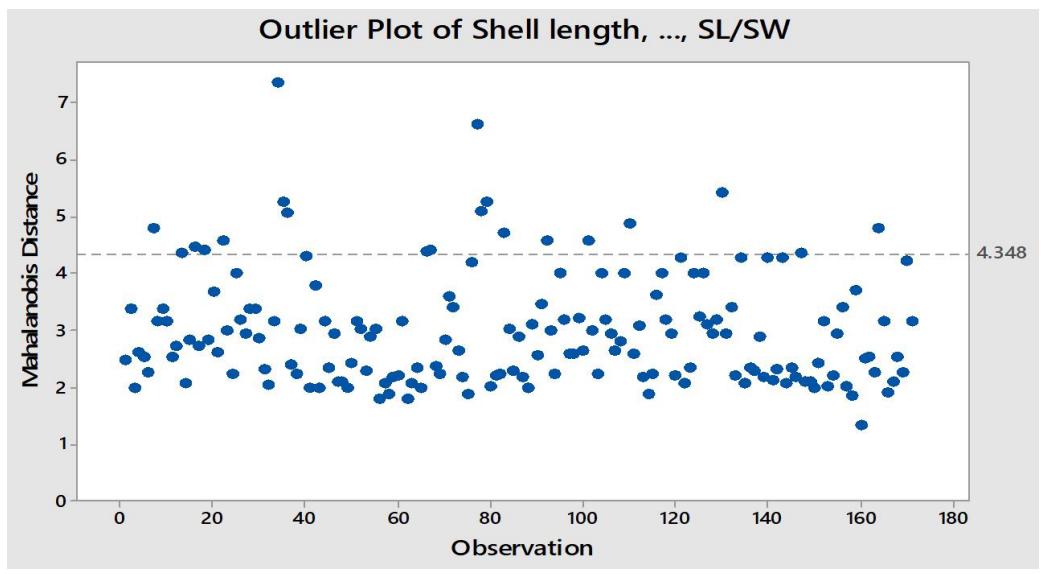

Figure 6. Outlier Plot between the Mahalanobis Distance and the Observation.

the identification of $P$. acuta, there were 79 numbers of specimens which were correctly identified out of total 98 available specimens. The correction proportion for $P$. acuta was $80.6 \%$. In the case of $P$. fontinalis, there were 52 members correctly identified out of total 68 number of specimens with correction proportion of $77.6 \%$. Number of $P$. gyrina was only 6 specimens from which only 3 members were correctly identified with $50 \%$ correction proportion which is very small. Due to such small number of $P$. gyrina specimens, they couldn't be used for collection and extract formation (Table 6)

\subsubsection{Square distance between groups}

Square distance between groups indicates that how far or how different the specie is from other species in terms of its morphological, qualitative and quantitative attributes. The distance between $P$. acuta and $P$. fontinalis is 5.4699, $P$. acuta and $P$. gyrina is 7.6411, $P$. fontinalis and $P$. gyrina is 16.6080 . These values indicate that $P$. acuta resembles with $P$. fontinalis, and both these specimens don't resemble with $P$. gyrina (Table 7).

\section{Discussion}

Three species of Physa were identified on the basis of morphometric analysis i.e. P. acuta, P. fontinalis, P. gyrina. These globally invasive species have been introduced unnoticed and their correct identification is important for biodiversity conservation (Ng et al., 2018) in Pakistan

In Physa acuta the aperture is bigger relatively than the other species. The colour of shell spindle and apertural lip in grown snail is white while the overall colour of snail is blackish or dark grey. Small golden yellow spots are visible on the mantle (Sritongtae et al., 2015). Physa acuta are found near the banks of lakes, ponds, rivers and running or stagnant water. They can tolerate all the eutrophic conditions, as long as they are short lived. They are today distributed worldwide but are native to Mediterranean region and now most frequent in North America and Europe (Dillon Junior et al., 2002).
Table 7. Squared Distance between three species of Genus Physa.

\begin{tabular}{lccc}
\hline \multicolumn{1}{c}{ Species } & P. acuta & P. fontinalis & P. gyrina \\
\hline P. acuta & 0 & 5.4699 & 7.6411 \\
P. fontinalis & 5.4699 & 0 & 16.608 \\
P. gyrina & 7.6411 & 16.608 & 0 \\
\hline
\end{tabular}

The shell of snail Physa fontinalis has no operculum but a spire is present. The shape of shell is like an inverted pyriform. It has 4-7 numbers of whorls with a sinistral symmetry. They have more shell height then the width. The height of shell is $8-12 \mathrm{~mm}$. The spire height of last whorl is small and it is predominating. The height of spire is less than the whole shell height. The lips of the shell can be thick or thin with a translucent glossy appearance (Jungbluth and Knorre, 2009). Physa fontinalis can be found in all the freshwater environments. It can be found in polluted as well as in non-polluted freshwater supported by the research of Watson and Dallwits (2005) and Altaf et al., (2017d). However, Physa fontinalis has been found in rare in villages of Faisalabad (Altaf, 2017d) with higher concentrations of arsenic (Aziz and Altaf, 2018) due to its sensitivity for arsenic (Canivet, et al., 2001). The snails of this species can be termed as sinistral pond snails (Bouchet and Rocroi, 2005). These Physids are also known as cockroaches of malacology due to the fact that they eat algae and fish food. Although in heavily populated regions due to water pollution the species is found threatened (Welter-Schultes, 2012) yet in Faisalabad the snail species diversity is highly significant and snails have achieved the status of pest (Altaf et al., 2016).

The Physa gyrina was found in very less numbers in agroecosystem in Punjab which might due to its sensitive nature. The members of the species of Physa gyrina has a rising spire with 4-6 fairly convex whorls in its shell. The colour of body is grey and has white and yellow dots on it. Physa gyrina can be known as pond snail. They can tolerate all ranges of water from polluted to non-polluted. http:// www.biokids.umich.edu/critters/Physa_gyrina/.According to our findings the Physa gyrina can be found in intermittent 
or permanent freshwater, this is supported by the research of Stewart (2006), Dillon Junior and Wethington (2004), Dillon Junior, (2000). Distribution of snails differs due to the difference in environmental variables of the habitats. These factors include vegetation, light, soil, water and other factors like this. The study of Nunes et al., 2012 supports the statement. .Numerous studies are conducted showing that snail growth and reproductive success differs with calcium availability (e.g. Wäreborn, 1970, 1992; Crowell, 1973, Gomot et al., 1989). Ireland (1991) found an increase in snail body mass, and in the shell mass/size ratio, with an increase in available the thinnest shells were found in snails on the most calcium-poor diets. The calcium also assists in reproductive functions of snails as calcium carbonate helps in the formations of egg albumen proteins and it is also used to form the shell of developing embryo. Snail abundance, biomass and size are correlated together. Hence the snails living in calcium rich soils have long and thick shells. In addition to all functions, calcium rich habitats support the large diversity of snails (Jubb et al., 2006).

The morphometric analysis was confirmed on the basis of linear regression analysis. Linear regression analysis of the AL/SW ratio vs AL and SL/SW ratio vs AL indicated that the slopes of both linear regression lines significantly suggested that elongation of shell length and enlargement of shell width do not probably contribute equally to the growth of Physa acuta. Shell structure has various characters which provide primary guide line for identification of snails in taxonomic literature (Kerney and Cameron, 1979). Shells morphometery has a useful information which help us to identify them and find relationship among the snails, which has been carried out among three species using linear regression (El-Wakil et al. 2011). The individuals of this genus can be reached to maturity between 5-7 $\mathrm{mm}$ to $15 \mathrm{~mm}$ (Wethington, 2004). Principal Component Analysis is performed for multivariate analysis to identify the smaller number of uncorrelated variables, Principal Components from data set. PCA explains the maximum amount of variance with the fewest number of Pricipal Components. This method of analysis for species identification has been previously supported and used for analysis of heretability of shell morphometrics of Physa acuta (Dillon Junior and Wethington, 2015). Theoreticians (Raup, 1966) have explored modeling approaches to compare the vast diversity of gastropod shell form naturally observed to that which might be possible. With the advent of multivariate morphometrics in the 1970s (Blackith and Reyment, 1971; Reyment et al., 1984), evolutionary biologists began analyzing gastropod shell morphology with principal components (Janson and Sundberg, 1983), discriminant functions (Dillon Junior, 1984).

These species when cultured in lab were found to be uniparental and producing viable offspring thus donot follow biological species concept and are homozygous in bred lines which is confirmed by Dubois et al. (2008) showing inbreeding coefficient FIS 1 or less with Hardy Weinberg equilibrium tests showing heterozygote deficits (Rousset and Raymond, 1997) due to which morphological characters are quite helpful in the species identification.

In the present study, we examined diversity of the three species of the genus Physa in Faisalabad Pakistan. The characterization of Physid species is extremely important as we have found potent bioactive substances showing antibacterial activity (Altaf et al.2018). The Physa fontinalis species have been found to have a negative interaction with other species of the region (Altaf et al.2017c) which might be due to the phenomenon antibiosis or ammenalism.

\section{Conclusion}

The three species of the Physids have been reported for the first time in this region and can be biologically controlled as a bioresource. The species specific typological markers are extremely important for the characterization as it will not only be important for the management of the species as pest but also to harvest the product of interest i.e. bioactive substances.

\section{Acknowledgements}

The authors acknowledges the University research grant by Government College University Faisalabad for carrying out the research activities.

\section{References}

ALBRECHT, C., KROLL, O., TERRAZAS, E.M. and WILKE, T., 2009. Invasion of ancient Lake Titicaca by the globally invasive Physa acuta (Gastropoda: Pulmonata: Hygrophila). Biological Invasions, vol. 11, pp. 1821-1826. http://dx.doi.org/10.1007/ s10530-008-9360-9.

ALTAF, J., QURESHI, N.A. and SIDDIQUI, M.J.I., 2017b. Taxonomic studies on the occurrence of the snails (Mollusca: Gastropods) in the agroecosystem. Journal of Biodiversity and Environmental Science, vol. 10, no. 1, pp. 240-252.

ALTAF, J., QURESHI, N.A. and SIDDIQUI, M.J.I., 2017c. Interaction of snail species in the agroecosystem. Journal of Biodiversity and Environmental Science, vol. 10, no. 1, pp. 169-182.

ALTAF, J., QURESHI, N.A. and SIDDIQUI, M.J.I., 2017d. Terrestrial snails as bioindicators of environmental degradation. Journal of Biodiversity and Environmental Science, vol. 10, pp. 253-264.

ALTAF, J., QURESHI, N.A., RAZA, S.H. and IQBAL, M.J., 2016. Assessment of diversity and distribution of Snails (Mollusca: Gastropoda) in the Agroecosystem of Faisalabad, Pakistan. Journal of Biodiversity and Environmental Sciences, vol. 8, no. 1, pp. 17-33.

ALTAF, J., RASOOL, M.H., AKHTAR, S., MANZOOR, M., YOUNAS, T., ANSARI, B., AHMAD, G., JABEEN, F., ALI, M. and MUNIR, R., 2018. Comparative evaluation of antibacterial activity of foot muscle extracts from genus Physa and genus Ceciloides (Mollusca: gastropoda). Pakistan Journal of Pharmaceutical Sciences, vol. 31, no. 4, suppl., pp. 1555-1563. PMid:30058548.

AZIZ, S. and ALTAF,J., 2018. Biomagnification and bioremediation of toxic heavy metals through snails of Genus Physa (Gastropoda:Mollusca). Faisalabad: Government College University Faisalabad. MPhil Thesis.

BEGUM, F., and NAZNEEN, S. 1991. Systematic study of molluscan fauna of Layari river, mesogastropoda (Suborder taenioglossa) Pakistan. Bangladesh Journal of Zoology, vol. 19, no. 1, pp. 107-121.

BLACKITH, R.E. and REYMENT, R.A., 1971. Multivariate morphometrics. New York: Academic Press. 
BOUCHET, P. and ROCROI, J. P., 2005. Classification and nomenclator of gastropod families. In: G.M. DAVIS, ed. Malacologia. Germany: Conch Books.

BURCH, J. B., 1982. Freshwater snails (Mollusca: Gastropoda) of North America. Cincinnati: Environmental Monitoring and Support Laboratory, Office of Research and Development, U.S.

CANIVET, V., CHAMBON, P. and GIBERT, J., 2001. Toxicity and bioaccumulation of arsenic and chromium in epigean and hypogean freshwater macroinvertebrates. Archives of Environmental Contamination and Toxicology, vol. 40, no. 3, pp. 345-354. http://dx.doi.org/10.1007/s002440010182. PMid:11443365.

CROWELL, K.L., 1973. Experimental zoogeography: introductions of mice to small islands. American Naturalist, vol. 107, no. 956, pp. 535-558. http://dx.doi.org/10.1086/282857.

DILLON JUNIOR, R.T. and JACQUEMIN, S.J., 2015. The heritability of shell morphometrics in the freshwater pulmonate gastropod Physa. PLoS One, vol. 10, no. 4, pp. e0121962. http://dx.doi. org/10.1371/journal.pone.0121962. PMid:25876155.

DILLON JUNIOR, R.T. and WETHINGTON, A.R., 2004. No choice mating experiments among six nominal taxa of the subgenus Physella (Basommatophora: physidae). Heldia, vol. 6, pp. 69-78.

DILLON JUNIOR, R.T., 1984. Reduce the non-genetic component of morphological variance in gonobass pfoxima. Malacologia, vol. 25, no. 2, pp. 503-511.

DILLON JUNIOR, R.T., 2000. The ecology of freshwater mollusks. Cambridge: Cambridge University Press, 509 pp. http://dx.doi. org/10.1017/СBO9780511542008.

DILLON JUNIOR, R.T., WETHINGTON, A.R., RHETT, J.M. and SMITH, T.P., 2002. Population of the European freshwater pulmonate Physa acuta are not reproductively isolated from American Physa heterostropha or Physa integra. Invertebrate Biology, vol. 121, no. 3, pp. 226-234. http://dx.doi.org/10.1111/j.1744-7410.2002. tb00062.x.

DUBOIS, D., PRADE, H. and SMETS, P., 2008. A definition of subjective possibilities. International Journal of Approximate Reasoning, vol. 48, no. 2, pp. 352-364. http://dx.doi.org/10.1016/j. ijar.2007.01.005.

EL-WAKIL, B.H., BANAJA, A.A. and AMER, A.S., 2011. Morphometric and genetic insight for three terrestrial snails in Taif Province of Saudi Arabia. World Applied Sciences Journal, vol. 14, no. 4, pp. 546-551.

GOMOT, A., GOMOT, L., BOUKRAA, S. and BRUCKERT, S., 1989. Influence of soil on the growth of the land snail Helix aspersa. An experimental study of the absorption route for the stimulating factors. The Journal of Molluscan Studies, vol. 55, no. 1, pp. 1-7. http://dx.doi.org/10.1093/mollus/55.1.1-a.

IRELAND, M.P., 1991. The effect of dietary calcium on growth, shell thickness and tissue calcium distribution in the snail Achatina fulica. Comparative Biochemistry and Physiology. Part A, Physiology, vol. 98, no. 1, pp. 111-116. http://dx.doi. org/10.1016/0300-9629(91)90587-3.

JANSON, K. and SUNDBERG, P., 1983. Multivariate morphometric analysis of two varieties of Littorina saxatilis from the Swedish west coast. Marine Biology, vol. 74, no. 1, pp. 49-53. http:// dx.doi.org/10.1007/BF00394274.

JUBB, M.R., WILKIN, T.A. and GOSLER, A.G., 2006. Eggshellpigmentation, soil calcium and the local abundance, distribution and diversity of woodland snails (Mollusca). Ardea, vol. 94, no. 1, pp. 59-70.

JUNGBLUTH, J. H., and KNORRE, D. V., 2009. Rote Liste der Binnenmollusken (Schnecken (Gastropoda) und Muscheln (Bivalvia) in Deutschland - 6. revidierte Fassung 2008. Mitt. dtsch. malakozool. Ges, vol. 81, pp. 1-28.
KAHLOWN, M.A., ASHRAF, M., HUSSAIN, M., SALAM, A. and BHATTI, A.Z., 2006. Impact Assessment of Sewerage and Industrial Effluents on Water Resources, Soil Crops and Human Health in Faisalabad. Islamabad: PCRWR. Research Report-6.

KERNEY, M.P. and CAMERON, R.A.D., 1979. A field guide to the land snails of Britain and north-west Europe. London: Harper Collins.

KHATOON, S. and ALI, S.R., 1978. Freshwater mollusks of Pakistan. Hydrobiological Bulletin, vol. 1, pp. 518-525.

NG, T.H., LIMPANONT, Y., CHUSONGSANG, Y., CHUSONGSANG, P. and PANHA, S., 2018. Correcting misidentifications and first confirmation of the globally-invasive Physa acuta Draparnaud, 1805 (Gastropoda: Physidae) in Thailand and Laos. BioInvasions Records, vol. 7, no. 1, pp. 15-19. http://dx.doi.org/10.3391/ bir.2018.7.1.03.

QAMAR, S., SAIF, A. and ALTAF, J., 2017. Identification of the species of genus Zootecus on the basis of morphology. Journal of Biodiversity and Environmental Sciences, vol. 11, no. 3, pp. 122-127.

RAUP, D., 1966. Geometric analysis of shell coiling: general problems. Journal of Paleontology, vol. 40, pp. 1178-1190.

REYMENT, R.A., BLACKITH R. E., and CAMPBELL N.A., 1984. Multivariate morphometrics. 2nd ed. New York: Academic Press.

ROUSSET, F. and RAYMOND, M., 1997. Statistical analyses of population genetic data: new tools, old concepts. Trends in Ecology \& Evolution, vol. 12, no. 8, pp. 313-317. http://dx.doi. org/10.1016/S0169-5347(97)01104-X. PMid:21238087.

SRITONGTAE, S., NAMCHOTE, S., KRAILAS, D., BOONMEKAM, D. and KOONCHORNBOON, T., 2015. Cercarial infections of brackish water snails on the east coast of southern Thailand. JITMM Proceedings, vol. 3, pp. 1-15.

STEWART, T.W., 2006. The freshwater gastropods of Iowa (18211998): species composition, geographic distributions, and conservation concerns. American Malacological Bulletin, vol. 21, pp. 59-75.

TE, G.A., 1978. The systematics of the family Physidae (Basommatophora: Pulmonata). Michigan: University of Michigan. PhD Thesis.

VASCONCELOS, P., and M. B. GASPAR, M. CASTRO, 2006. Development of indices for nonsacrificial sexing of imposex-affected Hexaplex (Trunculariopsis) Trunculus (Gastropoda: Muricidae).Journal of Molluscan Studies, vol. 72, no. 3, pp. 285-294.

WÄREBORN, I., 1970. Environmental factors influencing distribution of land molluscs of an oligotrophic area in southern Sweden. Oikos, vol. 21, no. 2, pp. 285-291. http:// dx.doi.org/10.2307/3543685.

WÄREBORN, I., 1992. Changes in the land mollusc fauna and soil chemistry in an inland district of southern Sweden. Ecography, vol. 15, no. 1, pp. 62-69. http://dx.doi. org/10.1111/j.1600-0587.1992.tb00009.x.

WATSON, L., and DALLWITZ, M. J., 2005 [viewed 24 December 2020]. The families of British non-marine molluscs (slugs, snails and mussels) [online]. Version: 4th January 2012. Delta data files. Available from: https://www.delta-intkey.com/britmo/ index.htm

WELTER-SCHULTES, F.W. (2012). European Non-Marine Molluscs, a Guide for Species Identification. Göttingen: Planet Poster Editions.

WETHINGTON, A.R. and LYDEARD, C., 2007. A molecular phylogeny of Physidae (Gastropoda: Basommatophora) based on mitochondrial DNA sequences. The Journal of Molluscan Studies, vol. 73, no. 3, pp. 241-257. http://dx.doi.org/10.1093/ mollus/eym021.

WETHINGTON, A.R., 2004. Phylogeny, taxonomy and evolution of reproductive isolation in Physa (Pulmonata: Physidae). Tuscaloosa: University of Alabama, 787 pp. PhD Dissertation. 